\title{
Optimal treatment of Alzheimer's disease psychosis: challenges and solutions
}

This article was published in the following Dove Press journal:

Neuropsychiatric Disease and Treatment

24 November 2014

Number of times this article has been viewed

Jeremy Koppel ${ }^{1,2}$

Blaine S Greenwald ${ }^{2}$

'The Feinstein Institute for Medical Research, North Shore-Long Island Jewish Health System, Manhasset, NY, USA; ${ }^{2}$ Zucker Hillside Hospital, Hofstra North Shore-Long Island Jewish School of Medicine, Glen Oaks, NY, USA

Correspondence: Jeremy Koppel The Feinstein Institute for Medical Research, North Shore-Long Island Jewish Health System, 350 Community Drive, Manhasset, NY I I030, USA

Fax + I 516562040 I

Email jkoppel@nshs.edu
Abstract: Psychotic symptoms emerging in the context of neurodegeneration as a consequence of Alzheimer's disease was recognized and documented by Alois Alzheimer himself in his description of the first reported case of the disease. Over a quarter of a century ago, in the context of attempting to develop prognostic markers of disease progression, psychosis was identified as an independent predictor of a more-rapid cognitive decline. This finding has been subsequently well replicated, rendering psychotic symptoms an important area of exploration in clinical history taking - above and beyond treatment necessity - as their presence has prognostic significance. Further, there is now a rapidly accreting body of research that suggests that psychosis in Alzheimer's disease ( $\mathrm{AD}+\mathrm{P})$ is a heritable disease subtype that enjoys neuropathological specificity and localization. There is now hope that the elucidation of the neurobiology of the syndrome will pave the way to translational research eventuating in new treatments. To date, however, the primary treatments employed in alleviating the suffering caused by AD+P are the atypical antipsychotics. These agents are approved by the US Food and Drug Administration for the treatment of schizophrenia, but they have only marginal efficacy in treating AD+P and are associated with troubling levels of morbidity and mortality. For clinical approaches to AD+P to be optimized, this syndrome must be disentangled from other primary psychotic disorders, and recent scientific advances must be translated into disease-specific therapeutic interventions. Here we provide a review of atypical antipsychotic efficacy in $\mathrm{AD}+\mathrm{P}$, followed by an overview of critical neurobiological observations that point towards a frontal, tau-mediated model of disease, and we suggest a new preclinical animal model for future translational research.

Keywords: Alzheimer's disease, antipsychotics, psychosis, tau, behavioral disturbance, agitation

\section{Introduction}

There is urgency to the problem of the need for efficacious drug treatment in the management of Alzheimer's disease with psychosis (AD+P). AD+P has grave consequence, particularly for caregivers, as it is associated with physical aggression, and caregivers are most often the victims. ${ }^{1-3}$ Violent behavior that is directed towards caregivers is disruptive of care at the very least, but can also be dangerous for those charged with providing a safe environment for those suffering with disease. Not only is aggressive behavior inherently troublesome for families, but perhaps in part because of the difficulty of managing these behaviors, the rates of institutionalization are much higher in AD patients who have exhibited violent behavior. ${ }^{4,5}$ Notably, in one study of participants with elevated levels of physical aggression, $80 \%$ had delusions. ${ }^{6}$ This suggests that psychosis at least aggravates the clinical course of $A D$, and creates profound caregiver stress that compounds the difficulty of taking care of a loved one with the cognitive impairment that is a defining feature of the illness.

Unfortunately, the current treatment approaches to $\mathrm{AD}+\mathrm{P}$, relying mostly on agents approved for the treatment of schizophrenia, have been largely disappointing. 
The efficacy of the atypical antipsychotics in the treatment of behavioral and psychological symptoms of dementia derived from randomized placebo-controlled trials - has been parsed many ways, owing in part to the broad range of rating scales employed as outcome measures and the spectrum of neurobehavioral syndromes associated with AD. Indeed, trials that have enrolled over 5,000 patients to date have included a number of different psychometric scales of behavioral impairment, including the Neuropsychiatric Inventory (NPI); the Brief Psychiatric Rating Scale (BPRS); the Cohen-Mansfield Agitation Inventory; the Clinical Global Impression of Change; the Clinical Global Impression of Severity; and the Behavioral Pathology in Alzheimer's Disease (BEHAVE-AD). Evaluating the efficacy of currently available treatments in $\mathrm{AD}+\mathrm{P}$ is challenging, as the only available data comprises subscales distilled from comprehensive agitation inventories.

The most recent and most comprehensive meta-analysis to date of randomized placebo-controlled trials in the treatment of the behavioral and psychological symptoms of dementia $^{7}$ suggests a consistent superiority of atypical agents (aripiprazole, quetiapine, olanzapine, risperidone) over placebo as measured with the aforementioned behavioral rating scales. In fact, when atypical agents are amalgamated and their efficacy data is compared with placebo, the most recent meta-analysis reveals that antipsychotics demonstrate a convincing superiority over placebo in the treatment of behavioral disturbances. Calculated mean differences and $95 \%$ confidence intervals on behavioral rating scales support this contention: BPRS, -1.58 (-2.52 to -0.65$)$; CohenMansfield Agitation Inventory, -1.84 ( -3.01 to -0.61$)$; NPI, -2.81 (-4.35 to -1.28$)$; Clinical Global Impression of Change, -0.32 ( -0.44 to -0.20$)$; Clinical Global Impression of Severity, -0.19 ( -0.3 to -0.09$)$. These data, especially in light of the BPRS differences, could be taken as evidence that atypical antipsychotics are efficacious in the treatment of $\mathrm{AD}+\mathrm{P}$.

A careful look at these studies, however, suggests the ironic truth that amongst therapies for behavioral disturbances in $\mathrm{AD}$, the atypical antipsychotics are inconsistent at best in the treatment of psychosis. Positive results from the above referenced meta-analytic data on BPRS total score outcomes do not necessarily reflect improvement in psychosis. The BPRS, (Overall and Gorham 1962, Psychological Report $)^{8}$ an inventory of psychopathology that has been extensively utilized in the evaluation of outcomes in schizophrenia and other psychotic illnesses, is a remarkably broad 18 -item scale. ${ }^{9}$ Only a few items could be interpreted with any relevance in $\mathrm{AD}+\mathrm{P}$ : hostility, suspiciousness, hallucinatory behavior, and perhaps unusual thought content and uncooperativeness. Although not included in the most recent meta-analysis, data on psychosis can be extracted from the majority of placebo-controlled clinical trials of antipsychotics in dementia populations by looking at psychosis subscores derived from the NPI, the BEHAVE-AD, and the BPRS (Table 1). Olanzapine has been evaluated in comparison with placebo over 6-36 weeks in nursing home patients and outpatients. ${ }^{10-12}$ In the first study, olanzapine at a dose of $5 \mathrm{mg}$ and $10 \mathrm{mg}$, but not $15 \mathrm{mg}$, was superior to placebo on the psychosis subscale total score derived from the nursing home version of the NPI, the NPI-NH (Table 1). ${ }^{10}$ In a second study of $1.0 \mathrm{mg}, 2.5 \mathrm{mg}, 5.0 \mathrm{mg}$, and $7.5 \mathrm{mg}$ doses of olanzapine, only the $7.5 \mathrm{mg}$ dose was superior to placebo as measured by the NPI-NH psychosis subscale. ${ }^{11}$ In the Clinical Antipsychotics Trials of Intervention EffectivenessAlzheimer's Disease (CATIE-AD) study, an outpatient study comparing flexible doses of atypical antipsychotics (olanzapine, quetiapine, risperidone) to placebo, olanzapine at a mean dose of $5.5 \mathrm{mg}$ was not superior to placebo on the psychosis factor of the BPRS. ${ }^{12}$ Two 10-week randomized placebo-controlled trials have investigated aripiprazole in the treatment of $\mathrm{AD}+\mathrm{P} .{ }^{13,14}$ In the first study, an outpatient study employing a flexible dose, aripiprazole at a mean dose of $10 \mathrm{mg}$ demonstrated superiority to placebo on the BPRS psychosis subscale but not on the NPI psychosis subscale. ${ }^{13}$ In a nursing home study, comparing aripiprazole at doses of $2 \mathrm{mg}, 5 \mathrm{mg}$, and $10 \mathrm{mg}$, only $10 \mathrm{mg}$ was superior to placebo on the NPI-NH psychosis subscale. ${ }^{14}$ Two studies, of 6 weeks and 36 weeks duration in nursing facilities and outpatient populations, respectively, have evaluated the efficacy of quetiapine in comparison with placebo for the treatment of $\mathrm{AD}+\mathrm{P} .{ }^{12,15}$ No evidence of efficacy in treating psychosis was generated for quetiapine from either study on the basis of the BPRS psychosis subscales. Prior to CATIE-AD, there were four randomized placebo-controlled trials of risperidone in $\mathrm{AD}+\mathrm{P}$, ranging from 8-36 weeks in both the nursing home residents and outpatients. ${ }^{16-19}$ A meta-analysis of these four studies revealed that risperidone was superior to placebo on the BEHAVE-AD psychosis subscale, with an effect size of 0.154 (95\% confidence interval 0.038-0.269), suggesting only a modest effect of drug treatment. ${ }^{20}$ Data from CATIE-AD also evidenced a benefit of risperidone over placebo on the BPRS psychosis factor, the only agent to beat placebo on this measure. ${ }^{12}$ The data on atypical antipsychotics, while inconsistent, do suggest some utility for most agents, with some superiority for risperidone; however, the magnitudes of 
Table I Randomized placebo-controlled trials of atypical antipsychotics in the treatment of Alzheimer's disease with psychosis

\begin{tabular}{|c|c|c|c|c|}
\hline Study & Agent & $\mathbf{N}$ & Outcome measure & Outcome \\
\hline Street et al ${ }^{10}$ & $\begin{array}{l}\text { Olanzapine } 5 \mathrm{mg}, 10 \mathrm{mg} \\
\text { versus placebo }\end{array}$ & 206 & NPI psychosis subscale & $\begin{array}{l}5 \mathrm{mg} \text { and } 10 \mathrm{mg} \text { superior to placebo, } \\
15 \mathrm{mg} \text { not superior to placebo }\end{array}$ \\
\hline De Deyn et al"' & $\begin{array}{l}\text { Olanzapine } 1.0 \mathrm{mg}, 2.5 \mathrm{mg} \text {, } \\
5.0 \mathrm{mg}, 7.5 \mathrm{mg} \text { versus } \\
\text { placebo }\end{array}$ & 652 & NPI psychosis subscale & $\begin{array}{l}7.5 \mathrm{mg} \text { superior to placebo; } 1.0 \mathrm{mg} \text {, } \\
2.5 \mathrm{mg}, 5.0 \mathrm{mg} \text { not superior to placebo }\end{array}$ \\
\hline De Deyn et $\mathrm{al}^{13}$ & Aripiprazole versus placebo & 208 & $\begin{array}{l}\text { BPRS psychosis subscale; } \\
\text { NPI psychosis subscale }\end{array}$ & $\begin{array}{l}\text { Mean dose } 10 \mathrm{mg} \text { superior to placebo } \\
\text { on BPRS psychosis subscale but not NPI } \\
\text { psychosis subscale }\end{array}$ \\
\hline Mintzer et $\mathrm{al}^{14}$ & $\begin{array}{l}\text { Aripiprazole } 2 \mathrm{mg}, 5 \mathrm{mg} \text {, } \\
10 \mathrm{mg} \text { versus placebo }\end{array}$ & 487 & NPI psychosis subscale & $\begin{array}{l}10 \mathrm{mg} \text { superior to placebo, } 2 \mathrm{mg}, 5 \mathrm{mg} \\
\text { not superior to placebo }\end{array}$ \\
\hline Tariot et al $\left.\right|^{15}$ & $\begin{array}{l}\text { Quetiapine versus } \\
\text { haloperidol versus placebo }\end{array}$ & 284 & BPRS thought disturbance & $\begin{array}{l}\text { Mean dose } 96.9 \mathrm{mg} \text { quetiapine, } 1.9 \mathrm{mg} \\
\text { haloperidol, neither superior to placebo }\end{array}$ \\
\hline $\begin{array}{l}\text { Katz et al }{ }^{20} \\
\text { Katz et al }{ }^{16} \\
\text { De Deyn et al }{ }^{17} \\
\text { Brodaty et }{ }^{18} \\
\text { Mintzer et }{ }^{19}{ }^{19}\end{array}$ & Risperidone vs placebo & 941 & $\begin{array}{l}\text { Meta-analysis of BEHAVE- } \\
\text { AD psychosis subscale }\end{array}$ & $\begin{array}{l}\text { Mean dose } 1.09 \mathrm{mg} \text { risperidone } \\
\text { superior to placebo, effect size } 0.154 \\
\text { (range } 95 \% \mathrm{Cl}, 0.038-0.269 \text { ) }\end{array}$ \\
\hline Sultzer et al ${ }^{12}$ & $\begin{array}{l}\text { Olanzapine versus } \\
\text { quetiapine versus } \\
\text { risperidone versus placebo }\end{array}$ & 421 & $\begin{array}{l}\text { BPRS psychosis subscale; } \\
\text { hostile suspiciousness factor }\end{array}$ & $\begin{array}{l}\text { Mean dose olanzapine } 5.5 \mathrm{mg} \text { superior } \\
\text { to placebo on hostile suspiciousness } \\
\text { but not psychosis subscale; } 56.5 \mathrm{mg} \\
\text { quetiapine not superior to placebo; } \\
\text { risperidone I mg superior to placebo } \\
\text { on both psychosis and hostile } \\
\text { suspiciousness subscale }\end{array}$ \\
\hline
\end{tabular}

Abbreviations: BEHAVE-AD, Behavioral Pathology in Alzheimer's Disease scale; BPRS, Brief Psychiatric Rating Scale; N, number; NPI, Neuropsychiatric Inventory; Cl, confidence interval.

treatment effects are not robust, and highly efficacious agents are desperately needed. One solution to this problem is to develop novel treatments based on the emerging neurobiology of $\mathrm{AD}+\mathrm{P}$, rather than relying on existing treatments for other psychotic conditions.

\section{Phenomenology in AD+P: theoretical considerations}

Psychotic symptoms in AD comprise delusions, with a reported prevalence of between $30 \%-40 \%,{ }^{21-24}$ and, to a smaller extent, hallucinations, with a prevalence of $5 \%-20 \% .^{21,23,25-27}$ The heritability of $\mathrm{AD}+\mathrm{P}$ has been firmly established $^{28}$ and is estimated to be between $30 \%-60 \% .{ }^{29}$ The persistence of untreated psychosis over time in Alzheimer's disease in individual patients has not been firmly established, but available evidence suggests that approximately $40 \%-50 \%$ of psychotic individuals will continue to manifest psychotic symptoms after 1 year. ${ }^{30}$ Rather than the bizarre delusions and complex network of unsubstantiated belief systems commonly seen in schizophrenia typified by logical impossibility and experiences alien to "ordinary life situations," ${ }^{31}$ the delusions in $\mathrm{AD}+\mathrm{P}$ generally involve rather narrow elaborations and distortions of actual experience. The delusions of $\mathrm{AD}$ have been largely reconciled into two categories, ${ }^{32,33}$ delusions of persecution (eg, theft, harm, jealousy, abandonment $)^{2,34-36}$ and delusions of misidentification (eg, phantom boarder, television images are animate, Capgras syndrome, house is not one's home), ${ }^{2,35-38}$ the latter having once been conceptualized as representing perceptual abnormalities, but actually representing ideational fixations. ${ }^{32,39,40}$ A category of "autobiographical delusions," ${ }^{32}$ for instance that a dead relative is still alive, has also been suggested, ${ }^{41}$ but these may be regarded as an extension of the misidentification domain.

A few theoretical models have been developed to explain the common emergence of psychosis in $\mathrm{AD}$ - particularly focused on delusions - in those otherwise not afflicted with mental illness. Carefully reviewed by Reeves et al ${ }^{32}$ the earliest of these ratiocinations suggested that psychosis results from a "logical attempt to understand the environment" in the context of degraded cognitive integrity. ${ }^{42}$ For instance, the common delusions in $\mathrm{AD}$ - theft, jealousy, misidentification, abandonment, phantom boarder, television images are animate $^{21,43,44}$ - are possible narrative confabulations that fill in the gaps or normalize the experiences of those confronted with a history they have become unmoored from, and who rely on a gradually eroding apparatus for discriminating object from representation. The most intuitive support for 
this model comes from the most prevalent delusion in AD, that people are hiding or stealing things, ${ }^{45-47}$ a potential confabulation that is entirely consistent with the primary cognitive deficit in $\mathrm{AD}$, accelerated forgetting. Alternatively, some have suggested that brain disease results in "release symptomatology"48 or that cognitive deficits germinate delusional ideas as a consequence of a "lack of corrective judgment" from other cortical structures. ${ }^{49}$ These conceptualizations, while interesting, are broad and speculative and do not really generate any testable scientific predictions. More recent work has been focused on concrete neurobiological correlates of psychotic $\mathrm{AD}$, and from that a glimpse of disease pathophysiology has begun to emerge.

\section{Cognitive course and mortality in AD+P: evidence for a distinct syndrome?}

The earliest specific reference to the problem of psychosis in the modern literature on Alzheimer's disease emerges in a Russian neuropsychiatric journal in $1964 .{ }^{50}$ It was another 20 years before critical observations were made that contributed to a reconceptualization of psychotic phenomena as expressions of a unique pathophysiological syndrome rather than a mere behavioral nuisance. In the context of searching for clinical signs that would predict the velocity of decline in $\mathrm{AD}$, psychosis - in addition to myoclonus and extrapyramidal signs - was found to be an early marker heralding a hastened deterioration. ${ }^{51,52}$ This observation was quickly replicated in several studies reinforcing the prognostic value of psychosis in relationship to decline. ${ }^{53,54}$ Studies focused on the exploration of risk factors for psychotic symptoms in AD have also consistently identified a greater burden of cognitive impairment as an independent risk factor for psychosis, with acceleration of decline emerging prior to the onset of psychosis. $24,46,55,56$

The features of accelerated cognitive impairment in $\mathrm{AD}+\mathrm{P}$ suggest some degree of frontal localization. In one study of AD+P and Alzheimer's disease without psychosis (AD-P) that compared subjects of similar duration of illness, age, and education, $\mathrm{AD}+\mathrm{P}$ subjects evidenced more impairment on tasks of frontal-lobe function, including the Wisconsin Card Sorting Test and the similarities subtest of the Wechsler Adult Intelligence Scale. ${ }^{57}$ Recent studies suggest that working memory performance, a test of frontal function depending largely on the dorsolateral prefrontal cortex, enjoys a unique association with psychosis in AD. Early evidence for this emerged from an epidemiological study of $\mathrm{AD}+\mathrm{P}$ risk factors, wherein performance on the digit span, a task of working memory, was observed to be a robust predictor of future psychosis in AD. ${ }^{24}$ Impressively, a one-standard-deviation improvement in this task reduced the risk of developing hallucinations or delusions by two thirds. In our own study of cognition in $\mathrm{AD}+\mathrm{P}$, we evaluated $\mathrm{AD}$ and performed stepwise regression of cognitive domains in order to determine whether any cognitive domains (memory, executive function, language) predicted psychosis. We found that of the wide spectrum of domains of cognition interrogated in the analysis, only working memory interacted with psychosis. $^{58}$

In order to replicate the finding and to determine whether working memory, beyond its mere association with the state of psychosis, might track uniquely with the accelerated decline in $\mathrm{AD}+\mathrm{P}$, we performed an analysis of cognitive data from the Alzheimer's Disease Neuroimaging Initiative (ADNI) study database. The ADNI database includes longitudinal cognitive data on subjects some of whom destined to become psychotic, as evidenced by psychometric ratings, over the course of the study. We hypothesized that digit-span performance, amongst available cognitive metrics, would decline more rapidly over time as a marker of the accelerated decline of $\mathrm{AD}+\mathrm{P}$. Results of the analysis demonstrated that digit-span performance is one of only two cognitive measures that decline more rapidly in $\mathrm{AD}+\mathrm{P}$ when compared with AD-P. ${ }^{59}$ It is not clear how impairment in working memory is etiologically related to $\mathrm{AD}+\mathrm{P}$. One possibility is that it is merely a byproduct of frontal degeneration, and not directly etiologically related; another is that accelerated frontal degeneration engenders working memory deficits, and that failures in working memory impair successful environmental surveillance in $\mathrm{AD}$, culminating in misinterpretations and psychosis.

Evidence of a more aggressive cognitive phenotype as a marker of virulence would predict an acceleration of overall decline and decreased survival rates in those with $\mathrm{AD}+\mathrm{P}$. It is puzzling, given the established relationship between rate of cognitive decline and mortality in $\mathrm{AD},{ }^{60,61}$ that most, ${ }^{53,60-65}$ but not all, ${ }^{66}$ early studies did not find an increased mortality rate in $\mathrm{AD}+\mathrm{P}$. More recent studies, with larger sample sizes and an enhanced follow-up with a more powerful statistical approach (Cox proportional hazard regression analysis) have consistently observed the predictive value of psychosis in AD survival. ${ }^{67-70}$

A parsimonious hypothesis that explains the accelerated cognitive deterioration with some specificity and the early demise of patients with $\mathrm{AD}+\mathrm{P}$ is that psychosis is a behavioral expression of a more-rapid neurodegenerative process that 
may be regional. If so, what regions are implicated? What are the neurochemical and neuropathological hallmarks of this distinct AD syndrome? Can answers to these questions point the way forward in developing new anti-AD+P treatments?

\section{Imaging correlates in AD+P: a predominance of frontal localization}

In the search for cerebral localization of deficit patterns in $\mathrm{AD}+\mathrm{P}$, investigators have, with varying levels of success related to sample sizes and heterogeneous subject composition, availed themselves of structural and functional neuroimaging. The literature on imaging in $\mathrm{AD}+\mathrm{P}$ has been recently reviewed and thoughtfully organized by Murray et $\mathrm{al}^{71}$ who separated the studies by methodological approach, including computed tomography, magnetic resonance imaging (MRI), single-photon emission computed tomography, and $\left[{ }^{18} \mathrm{~F}\right]$ fluorodeoxyglucose position emission tomography (PET) studies. As the authors highlight, with some variability and inconsistency, the preponderance of imaging evidence across methodologies implicate the frontal lobes. ${ }^{71}$ A computed tomography study investigating regional brain atrophy in $\mathrm{AD}+\mathrm{P}$ found that subjects with delusions demonstrated frontal and temporal patterns of asymmetric atrophy, compared with AD-P subjects. ${ }^{72}$ MRI studies of AD+P have generally implicated the frontal cortex, with both orbitofrontal and medial frontal involvement. ${ }^{73,74}$ PET studies - with only one exception ${ }^{75}$ - have consistently shown frontal hypometabolism in $\mathrm{AD}+\mathrm{P}$ relative to $\mathrm{AD}-\mathrm{P} .^{76-80} \mathrm{In}$ an analysis of a large, well-controlled sample drawn from the ADNI database, we observed a specific relationship between orbitofrontal hypometabolism and AD+P. ${ }^{59}$

\section{Neurotransmission in AD+P}

An early theory promulgated in an effort to explain the prevalence of psychosis in AD suggested that a preservation of dopaminergic tone in the context of early cholinergic deficits may result in a relative "hyperdopaminergic" state, with resultant psychosis. ${ }^{81}$ However evidence for a relative excess of dopaminergic tone has been limited. An early postmortem study of neurotransmission in psychotic AD did not identify any abnormalities in markers of dopamine signaling. ${ }^{82}$ One small postmortem study suggested a selective increase in D3 receptor availability. ${ }^{83}$ Further, using $\left[{ }^{11} \mathrm{C}\right]$-raclopride PET, a modest increase in tracer binding in the striatum was observed in a cohort of delusional patients, suggesting some increase in D3 availability. ${ }^{84}$ Yet, a recent comprehensive postmortem study of monoaminergic correlates of behavioral symptoms in AD did not observe any relationship between alterations in dopamine or dopamine metabolite concentrations in nine behaviorally and neurochemically relevant brain regions and psychotic symptoms in $\mathrm{AD} .^{85}$

Perturbations in serotonergic systems have been reported in postmortem studies of psychotic AD. A reduction of serotonin (5-HT) has been reported in several studies across several brain regions, ${ }^{82,86}$ as have altered $5-\mathrm{HT}_{6}$ receptor function ${ }^{87}$ and a reduction in cell counts in the dorsal raphe nucleus. ${ }^{88}$ In a recent study, a significant reduction in serotonergic tone comprising lower 5-hydroxyindoleacetic acid concentrations in the hippocampus and lower 5-HT concentrations in the superior temporal gyrus and cerebral cortex, correlated with dementia severity. ${ }^{85}$ It may be that the association observed in previous studies between psychosis in $\mathrm{AD}$ and reduced 5-HT may be related to regional disease severity in psychotic $\mathrm{AD}$, and not an independent risk factor for the emergence of the syndrome.

Although currently available agents have not achieved satisfying rates of success in treating $\mathrm{AD}+\mathrm{P}$, continued exploration of perturbations in neurotransmitter systems in $\mathrm{AD}+\mathrm{P}$, together with the advent of more-sophisticated supportive therapeutics, may prove helpful in treating this condition.

\section{Neuropathology in AD+P: a focus on tau}

The classical protein pathologies in Alzheimer's disease comprise extracellular amyloid-beta $(\mathrm{A} \beta)$ plaques and intracellular neurofibrillary tangles, composed primarily of hyperphosphorylated tau proteins. As $\mathrm{AD}+\mathrm{P}$ is a morerapidly progressing disease variant, with evidence of some localization of disease to the frontal cortex, neuropathological correlation studies are critical in the search for disease etiology. In general, evidence collected from neuropathological studies supports an association of $\mathrm{AD}+\mathrm{P}$ with tau, rather than $A \beta$ pathology. ${ }^{44}$ This is not entirely surprising, since in $\mathrm{AD}$ distribution of tangle pathology, rather than $\mathrm{A} \beta$ pathology, correlates most closely with disease severity. ${ }^{89}$ Postmortem studies consistently point to a heavier burden of tangle pathology in $\mathrm{AD}+\mathrm{P}$, with some localization in the frontal cortex..$^{82,88,90,91}$

In order to explore tau pathology in $\mathrm{AD}+\mathrm{P}$, our group accessed the ADNI database to look for cerebrospinal fluid (CSF) evidence of increased tau in AD+P. Previous reports have linked elevations of CSF total tau with the postmortem burden of neurofibrillary tangles, ${ }^{92,93}$ so we approached the data with the hypothesis that we would find elevations in 
total tau in $\mathrm{AD}+\mathrm{P}$ relative to $\mathrm{AD}-\mathrm{P}$ as a reflection of tangle pathology. Indeed, we found that of the three core CSF AD biomarkers (A $\beta$, total tau, phospho-tau), only elevation of total tau in CSF was statistically significantly associated with psychosis in $\mathrm{AD}$, driven by a robust association in females with $\mathrm{AD}+\mathrm{P} .{ }^{94}$ In a contemporaneous postmortem immunohistochemical study of the frontal cortex conducted by colleagues in the laboratory of Dr Robert Sweet, hyperphosphorylated tau (the main component of neurofibrillary tangles $)^{95}$ was overabundant in subjects with AD+P compared with AD-P, strengthening the association of $\mathrm{AD}+\mathrm{P}$ with tau. ${ }^{96}$

Recently, in collaboration with Dr. Sweet, we conducted a biochemical analysis of phospho-tau epitopes in AD+P using a high-sensitivity enzyme-linked immunosorbent assay (ELISA) developed in the laboratory of Dr Peter Davies. ${ }^{97}$ The ELISAs utilize highly specific monoclonal antibodies to phospho-tau epitopes that are representative of a range of tau pathology, from neuritic to pretangle to mature tangles. ${ }^{98}$ Our experiments were conducted on postmortem tissue samples from the superior frontal gyri of 71 subjects. As $\alpha$-synuclein pathology is known to contribute to a psychotic phenotype in dementia with Lewy bodies (DLB), we controlled for $\alpha$-synuclein pathology. ${ }^{99} \mathrm{We}$ observed in women with $\mathrm{AD}+\mathrm{P}$, but not in men with $\mathrm{AD}+\mathrm{P}$, a robust association with tau pathology. ${ }^{100}$ In females, while levels of nonpathogenic total tau as measured with DA31 antibody ELISA did not differ between $\mathrm{AD}+\mathrm{P}$ and $\mathrm{AD}-\mathrm{P}$ groups, pathogenic phospho-tau species did differ significantly. AD+P females had significantly higher levels of phosphorylated tau than did AD-P females at each epitope interrogated: Ser396/404 (PHF-1), Ser202 (CP13), Thr231 (RZ3), and Ser199/202/ Thr205 (AT8). Males with AD+P, all of whom were not suffering with clinical DLB prior to death, nonetheless had an increase in $\alpha$-synuclein pathology. In males this suggests that $\alpha$-synuclein may make a unique contribution to $\mathrm{AD}+\mathrm{P}$, while in females tau pathology may be the source of vulnerability.

Previously conducted neuropathology studies have not been parsed by sex. There is evidence, however, that female sex is an independent risk factor for psychosis in AD. ${ }^{30,46,101,102}$ There is some support for biological underpinnings of this distinction from imaging studies. An MRI study in $\mathrm{AD}+\mathrm{P}$ evidenced reduced frontotemporal cortical thickness in women, rather than in men, with $\mathrm{AD}+\mathrm{P} .{ }^{74}$ Additionally, cerebral perfusion patterns in $\mathrm{AD}+\mathrm{P}$ have been shown to be sex-specific. ${ }^{103}$ The significance of the sex specificity of the association of $\mathrm{AD}+\mathrm{P}$ with tau pathology is not yet clear, and more research is necessary to confirm this relationship.

\section{Future directions: a pathology- guided approach}

The published research in $\mathrm{AD}+\mathrm{P}$ points toward an accelerated cognitive decline, with a particular burden of impairment affecting performance on frontal tasks. There is strong evidence that degeneration is accelerated in the frontal cortex, likely mediated by tau pathology, especially in females. This suggests a model of $\mathrm{AD}+\mathrm{P}$ in which normative temporoparietal deficits of $\mathrm{AD}$ are complicated by an accelerated extension to the frontal cortex. There may be some sex specificity to this model, and the degree to which the frontal tauopathy of $\mathrm{AD}+\mathrm{P}$ is a female problem is not yet clear. However, the model, in identifying pathogenic proteins and localization, does enable translational research that may aid in illuminating in just what regions, and to what degree, tau pathology may contribute to the psychotic phenotype.

Animal models of psychiatric disease pose a particular challenge, in that the core of psychiatric illness is experience, something inaccessible in observations of animals that are language deficient. However, there is a long history of observing animals under conditions designed to serve as analogues of precipitants of human behavioral disorders and of studying physiological changes in these animals; a more recent history of observing animals with physiological changes known to be associated with human disease and of studying behavioral changes. In $\mathrm{AD}$, translational research relies to a large degree on the advent of transgenic mice carrying autosomal dominant mutations in human genes that are known to cause the disease, or to cause pathology associated with the disease. The mice, depending on the identity of the mutation, produce an abundance of $A \beta$-driven plaque or tau-driven neurofibrillary tangle pathology and display dense cognitive deficits. ${ }^{104}$ Curiously, to date, these models have only infrequently been employed to study the behavioral syndromes so common in AD. This raises interesting questions. Are there outcome measures in mice relevant to psychosis that could be utilized in such an exploration? If so, could extant mouse models be employed to elucidate the neuropathological substrate responsible for $\mathrm{AD}+\mathrm{P}$ ? If $\mathrm{AD}+\mathrm{P}$ in humans emerges, in part, secondary to frontal neurodegeneration driven by tau, could a mouse model aid in a more-precise localization of the frontal deficits responsible?

Currently employed paradigms for modeling psychosis in mice include induction of locomotor hyperactivity and 
disruption of sensorimotor gating, quantified with prepulse inhibition (PPI) of acoustic startle. ${ }^{105}$ Locomotor hyperactivity, as a model of psychosis in rodents resulting from exogenous agents promoting dopamine release, is the conceptual offspring of the hyperdopaminergic hypothesis of schizophrenia; ${ }^{106}$ deficits of PPI represent an endophenotype of psychosis itself that has been associated with schizophrenia and may have broad relevance in all psychotic states. ${ }^{107} \mathrm{PPI}$ is defined as the reduction of the intensity of motor startle in response to a startle stimulus (for example, acoustic) when the stimulus is preceded by a diminished, nonstartle stimulus. In a normal state, the startle induced by the startle stimulus should be significantly gated by the attention paid to the preceding stimulus. In psychosis, this ability to inhibit startle is disrupted by a failure of normal gaiting, perhaps representing a diminished capacity to monitor environmental stimuli appropriately. ${ }^{108}$ PPI of acoustic startle as a phenotypic marker of psychosis may be best described as "the interface of psychosis and cognition," 105,109 representing a cognitive failure that potentially influences environmental surveillance and may promote psychotic misinterpretation. The confluence of cognitive impairment and environmental misapprehension implicit in PPI deficiency makes PPI an attractive outcome measure in investigating potential animal models of $\mathrm{AD}+\mathrm{P}$.

In order to develop a preclinical mouse model of $\mathrm{AD}+\mathrm{P}$, we recently selected an AD model manifesting early frontal tauopathy, the transgenic $\operatorname{rTg}\left(\operatorname{tau}_{\mathrm{P} 301 \mathrm{~L}}\right) 4510$ mouse, ${ }^{110}$ and characterized PPI deficits over time in relationship to tau pathology. ${ }^{111}$ We demonstrated that PPI deficits accrued over time in female $\mathrm{rTg}\left(\operatorname{tau}_{\mathrm{P} 301 \mathrm{~L}}\right) 4510$ mice, and that these deficits were driven by the same pathogenic hyperphosphorylated tau molecules that we had previously observed in the frontal cortex of human female AD+P subjects. ${ }^{100}$ This suggests that the $\operatorname{rgg}\left(\operatorname{tau}_{\mathrm{P} 301 \mathrm{~L}}\right) 4510$ mouse may be a candidate for preclinical study of $\mathrm{AD}+\mathrm{P}$ biology and the development of novel therapeutics. There is more work to be done prior to settling on any animal model of AD+P. Future studies involving this model will include expanding the phenotypic characterization of this mouse beyond PPI to include other cognitive and behavioral markers of psychosis, and exploring the sex specificity of the observed behavioral characteristics.

The way forward in the treatment of AD+P may transcend traditional psychiatric treatments of psychosis and may involve the reduction of pathogenic proteins rather than supporting aberrant neurotransmitter systems that are the downstream effects of disease pathology. Future treatments may focus on tau pathology, $\alpha$-synuclein pathology, or both. Several tau reduction agents are currently in the drug development stage for the treatment of AD, and even if they do not provide a cure for the primary illness, they warrant exploration in the service of combating a particularly morbid and common manifestation of the disease.

\section{Disclosure}

The authors report no conflicts of interest in this work.

\section{References}

1. Aarsland D, Cummings JL, Yenner G, Miller B. Relationship of aggressive behavior to other neuropsychiatric symptoms in patients with Alzheimer's disease. Am J Psychiatry. 1996;153(2):243-247.

2. Deutsch LH, Bylsma FW, Rovner BW, Steele C, Folstein MF. Psychosis and physical aggression in probable Alzheimer's disease. Am J Psychiatry. 1991;148(9):1159-1163.

3. Kunik ME, Snow-Turek AL, Iqbal N, et al. Contribution of psychosis and depression to behavioral disturbances in geropsychiatric inpatients with dementia. J Gerontol A Biol Sci Med Sci. 1999;54(3):M157-M161.

4. Knopman DS, Kitto J, Deinard S, Heiring J. Longitudinal study of death and institutionalization in patients with primary degenerative dementia. J Am Geriatr Soc. 1988;36(2):108-112.

5. O'Donnell BF, Drachman DA, Barnes HJ, Peterson KE, Swearer JM, Lew RA. Incontinence and troublesome behaviors predict institutionalization in dementia. J Geriatr Psychiatry Neurol. 1992;5(1):45-52.

6. Gilley DW, Wilson RS, Beckett LA, Evans DA. Psychotic symptoms and physically aggressive behavior in Alzheimer's disease. J Am Geriatr Soc. 1997;45(9):1074-1079.

7. Ma H, Huang Y, Cong Z, et al. The efficacy and safety of atypical antipsychotics for the treatment of dementia: a meta-analysis of randomized placebo-controlled trials. J Alzheimers Dis. 2014;42(3):915-937.

8. Overall JE, Gorham DR. The Brief Psychiatric Rating Scale. Psychological Report. 1962;10:799-812.

9. Rhoades HM, Overall JE. The semistructured BPRS interview and rating guide. Psychopharmacol Bull. 1988;24(1):101-104.

10. Street JS, Clark WS, Gannon KS, et al. Olanzapine treatment of psychotic and behavioral symptoms in patients with Alzheimer disease in nursing care facilities: a double-blind, randomized, placebo-controlled trial. The HGEU Study Group. Arch Gen Psychiatry. 2000;57(10): 968-976.

11. De Deyn PP, Carrasco MM, Deberdt W, et al. Olanzapine versus placebo in the treatment of psychosis with or without associated behavioral disturbances in patients with Alzheimer's disease. Int J Geriatr Psychiatry. 2004;19(2):115-126.

12. Sultzer DL, Davis SM, Tariot PN, et al; CATIE-AD Study Group. Clinical symptom responses to atypical antipsychotic medications in Alzheimer's disease: phase 1 outcomes from the CATIE-AD effectiveness trial. Am J Psychiatry. 2008;165(7):844-854.

13. De Deyn P, Jeste DV, Swanink R, et al. Aripiprazole for the treatment of psychosis in patients with Alzheimer's disease: a randomized, placebocontrolled study. J Clin Psychopharmacol. 2005;25(5):463-467.

14. Mintzer JE, Tune LE, Breder CD, et al. Aripiprazole for the treatment of psychoses in institutionalized patients with Alzheimer dementia: a multicenter, randomized, double-blind, placebo-controlled assessment of three fixed doses. Am J Geriatr Psychiatry. 2007;15(11):918-931.

15. Tariot PN, Schneider L, Katz IR, et al. Quetiapine treatment of psychosis associated with dementia: a double-blind, randomized, placebo-controlled clinical trial. Am J Geriatr Psychiatry. 2006;14(9): 767-776.

16. Katz IR, Jeste DV, Mintzer JE, Clyde C, Napolitano J, Brecher M. Comparison of risperidone and placebo for psychosis and behavioral disturbances associated with dementia: a randomized, double-blind trial. Risperidone Study Group. J Clin Psychiatry. 1999;60(2): 107-115. 
17. De Deyn PP, Rabheru K, Rasmussen A, et al. A randomized trial of risperidone, placebo, and haloperidol for behavioral symptoms of dementia. Neurology. 1999;53(5):946-955.

18. Brodaty H, Ames D, Snowdon J, et al. A randomized placebo-controlled trial of risperidone for the treatment of aggression, agitation, and psychosis of dementia. J Clin Psychiatry. 2003;64(2):134-143.

19. Mintzer J, Greenspan A, Caers I, et al. Risperidone in the treatment of psychosis of Alzheimer disease: results from a prospective clinical trial. Am J Geriatr Psychiatry. 2006;14(3):280-291.

20. Katz I, de Deyn PP, Mintzer J, Greenspan A, Zhu Y, Brodaty H. The efficacy and safety of risperidone in the treatment of psychosis of Alzheimer's disease and mixed dementia: a meta-analysis of 4 placebo-controlled clinical trials. Int J Geriatr Psychiatry. 2007;22(5): 475-484.

21. Sultzer DL. Psychosis and antipsychotic medications in Alzheimer's disease: clinical management and research perspectives. Dement Geriatr Cogn Disord. 2004;17(1-2):78-90.

22. Flint AJ. Delusions in dementia: a review. J Neuropsychiatry Clin Neurosci. 1991;3(2):121-130.

23. Sultzer DL, Levin HS, Mahler ME, High WM, Cummings JL. Assessment of cognitive, psychiatric, and behavioral disturbances in patients with dementia: the Neurobehavioral Rating Scale. J Am Geriatr Soc. 1992;40(6):549-555.

24. Paulsen JS, Salmon DP, Thal LJ, et al. Incidence of and risk factors for hallucinations and delusions in patients with probable AD. Neurology. 2000;54(10):1965-1971.

25. Devanand DP, Jacobs DM, Tang MX, et al. The course of psychopathologic features in mild to moderate Alzheimer disease. Arch Gen Psychiatry. 1997;54(3):257-263.

26. Mega MS, Cummings JL, Fiorello T, Gornbein J. The spectrum of behavioral changes in Alzheimer's disease. Neurology. 1996;46(1): $130-135$.

27. Lyketsos CG, Steinberg M, Tschanz JT, Norton MC, Steffens DC, Breitner JC. Mental and behavioral disturbances in dementia: findings from the Cache County Study on Memory in Aging. Am J Psychiatry. 2000;157(5):708-714

28. Sweet RA, Nimgaonkar VL, Devlin B, Lopez OL, DeKosky ST. Increased familial risk of the psychotic phenotype of Alzheimer disease. Neurology. 2002;58(6):907-911.

29. Bacanu SA, Devlin B, Chowdari KV, DeKosky ST, Nimgaonkar VL, Sweet RA. Heritability of psychosis in Alzheimer disease. Am J Geriatr Psychiatry. 2005;13(7):624-627.

30. Schneider LS, Dagerman KS. Psychosis of Alzheimer's disease: clinical characteristics and history. J Psychiatr Res. 2004;38(1):105-111.

31. Cermolacce M, Sass L, Parnas J. What is bizarre in bizarre delusions? A critical review. Schizophr Bull. 2010;36(4):667-679.

32. Reeves SJ, Gould RL, Powell JF, Howard RJ. Origins of delusions in Alzheimer's disease. Neurosci Biobehav Rev. 2012;36(10): 2274-2287.

33. Cook SE, Miyahara S, Bacanu SA, et al. Psychotic symptoms in Alzheimer disease: evidence for subtypes. Am J Geriatr Psychiatry. 2003;11(4):406-413.

34. Burns A, Jacoby R, Levy R. Psychiatric phenomena in Alzheimer's disease. I: disorders of thought content. Br JPsychiatry. 1990;157:72-76, 92-94.

35. Reisberg B, Borenstein J, Salob SP, Ferris SH, Franssen E, Georgotas A. Behavioral symptoms in Alzheimer's disease: phenomenology and treatment. J Clin Psychiatry. 1987;48 Suppl:9-15.

36. Rubin EH, Drevets WC, Burke WJ. The nature of psychotic symptoms in senile dementia of the Alzheimer type. J Geriatr Psychiatry Neurol. 1988;1(1):16-20.

37. Burns A, Jacoby R, Levy R. Psychiatric phenomena in Alzheimer's disease. II: disorders of perception. Br J Psychiatry. 1990;157:76-81, 92-94.

38. Merriam AE, Aronson MK, Gaston P, Wey SL, Katz I. The psychiatric symptoms of Alzheimer's disease. J Am Geriatr Soc. 1988;36(1): $7-12$.
39. Gormley N, Rizwan MR. Prevalence and clinical correlates of psychotic symptoms in Alzheimer's disease. Int J Geriatr Psychiatry. 1998;13(6): $410-414$.

40. Hwang JP, Yang CH, Tsai SJ. Phantom boarder symptom in dementia. Int J Geriatr Psychiatry. 2003;18(5):417-420.

41. Venneri A, Shanks MF, Staff RT, Della Sala S. Nurturing syndrome: a form of pathological bereavement with delusions in Alzheimer's disease. Neuropsychologia. 2000;38(2):213-224.

42. Rabins PV, Mace NL, Lucas MJ. The impact of dementia on the family. JAMA. 1982;248(3):333-335.

43. Jeste DV, Finkel SI. Psychosis of Alzheimer's disease and related dementias. Diagnostic criteria for a distinct syndrome. Am J Geriatr Psychiatry. 2000;8(1):29-34.

44. Murray PS, Kumar S, Demichele-Sweet MA, Sweet RA. Psychosis in Alzheimer's disease. Biol Psychiatry. 2014;75(7):542-552.

45. Cummings JL, Miller B, Hill MA, Neshkes R. Neuropsychiatric aspects of multi-infarct dementia and dementia of the Alzheimer type. Arch Neurol. 1987;44(4):389-393.

46. Hirono N, Mori E, Yasuda M, et al. Factors associated with psychotic symptoms in Alzheimer's disease. J Neurol Neurosurg Psychiatry. 1998; 64(5):648-652.

47. Ropacki SA, Jeste DV. Epidemiology of and risk factors for psychosis of Alzheimer's disease: a review of 55 studies published from 1990 to 2003. Am J Psychiatry. 2005;162(11):2022-2030.

48. Berrios GE. Non-cognitive symptoms and the diagnosis of dementia. Historical and clinical aspects. Br J Psychiatry Suppl. 1989;(4):11-16.

49. Malloy PF, Richardson ED. The frontal lobes and content-specific delusions. J Neuropsychiatry Clin Neurosci. 1994;6(4):455-466.

50. Shakhmatov NF. [On psychotic pictures observed during the course of Alzheimer's disease and Pick's disease]. Zh Nevropatol Psikhiatr Im S S Korsakova. 1964;64:265-269. Russian.

51. Mayeux R, Stern Y, Spanton S. Heterogeneity in dementia of the Alzheimer type: evidence of subgroups. Neurology. 1985;35(4): 453-461.

52. Stern Y, Mayeux R, Sano M, Hauser WA, Bush T. Predictors of disease course in patients with probable Alzheimer's disease. Neurology. 1987; 37(10):1649-1653.

53. Drevets WC, Rubin EH. Psychotic symptoms and the longitudinal course of senile dementia of the Alzheimer type. Biol Psychiatry. 1989; 25(1):39-48.

54. Rosen J, Zubenko GS. Emergence of psychosis and depression in the longitudinal evaluation of Alzheimer's disease. Biol Psychiatry. 1991; 29(3):224-232.

55. Wilson RS, Gilley DW, Bennett DA, Beckett LA, Evans DA. Hallucinations, delusions, and cognitive decline in Alzheimer's disease. J Neurol Neurosurg Psychiatry. 2000;69(2):172-177.

56. Emanuel JE, Lopez OL, Houck PR, et al. Trajectory of cognitive decline as a predictor of psychosis in early Alzheimer disease in the cardiovascular health study. Am J Geriatr Psychiatry. 2011;19(2):160-168.

57. Jeste DV, Wragg RE, Salmon DP, Harris MJ, Thal LJ. Cognitive deficits of patients with Alzheimer's disease with and without delusions. Am J Psychiatry. 1992;149(2):184-189.

58. Koppel J, Goldberg TE, Gordon ML, et al. Relationships between behavioral syndromes and cognitive domains in Alzheimer disease: the impact of mood and psychosis. Am J Geriatr Psychiatry. 2012;20(11): 994-1000.

59. Koppel J, Sunday S, Goldberg TE, Davies P, Christen E, Greenwald BS; Alzheimer's Disease Neuroimaging Initiative. Psychosis in Alzheimer's disease is associated with frontal metabolic impairment and accelerated decline in working memory: findings from the Alzheimer's Disease Neuroimaging Initiative. Am J Geriatr Psychiatry. 2014;22(7):698-707.

60. Hui JS, Wilson RS, Bennett DA, Bienias JL, Gilley DW, Evans DA. Rate of cognitive decline and mortality in Alzheimer's disease. Neurology. 2003;61(10):1356-1361.

61. Heyman A, Wilkinson WE, Hurwitz BJ, et al. Early-onset Alzheimer's disease: clinical predictors of institutionalization and death. Neurology. 1987;37(6):980-984. 
62. Burns A, Lewis G, Jacoby R, Levy R. Factors affecting survival in Alzheimer's disease. Psychol Med. 1991;21(2):363-370.

63. Lopez OL, Wisniewski SR, Becker JT, Boller F, DeKosky ST. Psychiatric medication and abnormal behavior as predictors of progression in probable Alzheimer disease. Arch Neurol. 1999;56(10):1266-1272.

64. Samson WN, van Duijn CM, Hop WC, Hofman A. Clinical features and mortality in patients with early-onset Alzheimer's disease. Eur Neurol. 1996;36(2):103-106.

65. Stern Y, Tang MX, Albert MS, et al. Predicting time to nursing home care and death in individuals with Alzheimer disease. JAMA. 1997; 277(10):806-812.

66. Moritz DJ, Fox PJ, Luscombe FA, Kraemer HC. Neurological and psychiatric predictors of mortality in patients with Alzheimer disease in California. Arch Neurol. 1997;54(7):878-885.

67. Scarmeas N, Brandt J, Albert M, et al. Delusions and hallucinations are associated with worse outcome in Alzheimer disease. Arch Neurol. 2005;62(10):1601-1608.

68. Wilson RS, Krueger KR, Kamenetsky JM, et al. Hallucinations and mortality in Alzheimer disease. Am J Geriatr Psychiatry. 2005;13(11): 984-990.

69. Vilalta-Franch J, López-Pousa S, Calvó-Perxas L, Garre-Olmo J. Psychosis of Alzheimer disease: prevalence, incidence, persistence, risk factors, and mortality. Am J Geriatr Psychiatry. 2013;21(11): 1135-1143.

70. Lopez OL, Becker JT, Chang YF, et al. The long-term effects of conventional and atypical antipsychotics in patients with probable Alzheimer's disease. Am J Psychiatry. 2013;170(9):1051-1058.

71. Murray PS, Kumar S, Demichele-Sweet MA, Sweet RA. Psychosis in Alzheimer's disease. Biol Psychiatry. 2014;75(7):542-552.

72. Geroldi C, Bresciani L, Zanetti O, Frisoni GB. Regional brain atrophy in patients with mild Alzheimer's disease and delusions. Int Psychogeriatr. 2002;14(4):365-378

73. Bruen PD, McGeown WJ, Shanks MF, Venneri A. Neuroanatomical correlates of neuropsychiatric symptoms in Alzheimer's disease. Brain. 2008;131(Pt 9):2455-2463.

74. Whitehead D, Tunnard C, Hurt C, et al; AddNeuroMed Consortium. Frontotemporal atrophy associated with paranoid delusions in women with Alzheimer's disease. Int Psychogeriatr. 2012;24(1):99-107.

75. Hirono N, Mori E, Ishii K, et al. Alteration of regional cerebral glucose utilization with delusions in Alzheimer's disease. J Neuropsychiatry Clin Neurosci. 1998;10(4):433-439.

76. Mentis MJ, Weinstein EA, Horwitz B, et al. Abnormal brain glucose metabolism in the delusional misidentification syndromes: a positron emission tomography study in Alzheimer disease. Biol Psychiatry. 1995;38(7):438-449.

77. Sultzer DL, Mahler ME, Mandelkern MA, et al. The relationship between psychiatric symptoms and regional cortical metabolism in Alzheimer's disease. J Neuropsychiatry Clin Neurosci. 1995;7(4):476-484.

78. Lopez OL, Smith G, Becker JT, Meltzer CC, DeKosky ST. The psychotic phenomenon in probable Alzheimer's disease: a positron emission tomography study. J Neuropsychiatry Clin Neurosci. 2001;13(1):50-55.

79. Grady CL, Haxby JV, Schapiro MB, et al. Subgroups in dementia of the Alzheimer type identified using positron emission tomography. J Neuropsychiatry Clin Neurosci. 1990;2(4):373-384.

80. Sultzer DL, Brown CV, Mandelkern MA, et al. Delusional thoughts and regional frontal/temporal cortex metabolism in Alzheimer's disease. Am J Psychiatry. 2003;160(2):341-349.

81. Cummings JL, Back C. The cholinergic hypothesis of neuropsychiatric symptoms in Alzheimer's disease. Am J Geriatr Psychiatry. 1998; 6(2 Suppl 1):S64-S78.

82. Zubenko GS, Moossy J, Martinez AJ, et al. Neuropathologic and neurochemical correlates of psychosis in primary dementia. Arch Neurol. 1991;48(6):619-624.

83. Sweet RA, Hamilton RL, Healy MT, et al. Alterations of striatal dopamine receptor binding in Alzheimer disease are associated with Lewy body pathology and antemortem psychosis. Arch Neurol. 2001;58(3): 466-472.
84. Reeves S, Brown R, Howard R, Grasby P. Increased striatal dopamine (D2/D3) receptor availability and delusions in Alzheimer disease. Neurology. 2009;72(6):528-534.

85. Vermeiren Y, Van Dam D, Aerts T, Engelborghs S, De Deyn PP. Brain region-specific monoaminergic correlates of neuropsychiatric symptoms in Alzheimer's disease. J Alzheimers Dis. 2014;41(3): 819-833.

86. Garcia-Alloza M, Gil-Bea FJ, Diez-Ariza M, et al. Cholinergic-serotonergic imbalance contributes to cognitive and behavioral symptoms in Alzheimer's disease. Neuropsychologia. 2005;43(3):442-449.

87. Marcos B, García-Alloza M, Gil-Bea FJ, et al. Involvement of an altered 5-HT- $\{6\}$ receptor function in behavioral symptoms of Alzheimer's disease. J Alzheimers Dis. 2008;14(1):43-50.

88. Förstl H, Burns A, Levy R, Cairns N. Neuropathological correlates of psychotic phenomena in confirmed Alzheimer's disease. Br J Psychiatry. 1994;165(1):53-59.

89. Arriagada PV, Growdon JH, Hedley-Whyte ET, Hyman BT. Neurofibrillary tangles but not senile plaques parallel duration and severity of Alzheimer's disease. Neurology. 1992;42(3 Pt 1):631-639.

90. Zubenko GS. Molecular neurobiology of Alzheimer's disease (syndrome?). Harv Rev Psychiatry. 1997;5(4):177-213.

91. Farber NB, Rubin EH, Newcomer JW, et al. Increased neocortical neurofibrillary tangle density in subjects with Alzheimer disease and psychosis. Arch Gen Psychiatry. 2000;57(12):1165-1173.

92. Clark CM, Xie S, Chittams J, et al. Cerebrospinal fluid tau and betaamyloid: how well do these biomarkers reflect autopsy-confirmed dementia diagnoses? Arch Neurol. 2003;60(12):1696-1702.

93. Tapiola T, Overmyer M, Lehtovirta M, et al. The level of cerebrospinal fluid tau correlates with neurofibrillary tangles in Alzheimer's disease. Neuroreport. 1997;8(18):3961-3963.

94. Koppel J, Sunday S, Buthorn J, Goldberg T, Davies P, Greenwald B; Alzheimer's Disease Neuroimaging Initiative. Elevated CSF Tau is associated with psychosis in Alzheimer's disease. Am J Psychiatry. 2013;170(10):1212-1213.

95. Crowther RA, Olesen OF, Jakes R, Goedert M. The microtubule binding repeats of tau protein assemble into filaments like those found in Alzheimer's disease. FEBS Lett. 1992;309(2):199-202.

96. Murray PS, Kirkwood CM, Gray MC, et al. Hyperphosphorylated tau is elevated in Alzheimer's disease with psychosis. J Alzheimers Dis. 2014;39(4):759-773.

97. Acker CM, Forest SK, Zinkowski R, Davies P, d'Abramo C. Sensitive quantitative assays for tau and phospho-tau in transgenic mouse models. Neurobiol Aging. 2013;34(1):338-350.

98. Augustinack JC, Schneider A, Mandelkow EM, Hyman BT. Specific tau phosphorylation sites correlate with severity of neuronal cytopathology in Alzheimer's disease. Acta Neuropathol. 2002;103(1):26-35.

99. McKeith IG, Dickson DW, Lowe J, et al; Consortium on DLB. Diagnosis and management of dementia with Lewy bodies: third report of the DLB Consortium. Neurology. 2005;65(12):1863-1872.

100. Koppel J, Acker C, Davies P, et al. Psychotic Alzheimer's disease is associated with gender-specific tau phosphorylation abnormalities. Neurobiol Aging. 2014;35(9):2021-2028.

101. Rockwell E, Krull AJ, Dimsdale J, Jeste DV. Late-onset psychosis with somatic delusions. Psychosomatics. 1994;35(1):66-72.

102. Leroi I, Voulgari A, Breitner JC, Lyketsos CG. The epidemiology of psychosis in dementia. Am J Geriatr Psychiatry. 2003;11(1): 83-91.

103. Moran EK, Becker JA, Satlin A, Lyoo IK, Fischman AJ, Johnson KA. Psychosis of Alzheimer's disease: Gender differences in regional perfusion. Neurobiol Aging. 2008;29(8):1218-1225.

104. LaFerla FM, Green KN. Animal models of Alzheimer disease. Cold Spring Harb Perspect Med. 2012;2(11).

105. van den Buuse M. Modeling the positive symptoms of schizophrenia in genetically modified mice: pharmacology and methodology aspects. Schizophr Bull. 2010;36(2):246-270.

106. Laruelle M, Abi-Dargham A, Gil R, Kegeles L, Innis R. Increased dopamine transmission in schizophrenia: relationship to illness phases. Biol Psychiatry. 1999;46(1):56-72. 
107. Braff D, Stone C, Callaway E, Geyer M, Glick I, Bali L. Prestimulus effects on human startle reflex in normals and schizophrenics. Psychophysiology. 1978;15(4):339-343.

108. Ouagazzal AM, Jenck F, Moreau JL. Drug-induced potentiation of prepulse inhibition of acoustic startle reflex in mice: a model for detecting antipsychotic activity? Psychopharmacology (Berl). 2001; 156(2-3):273-283

109. Desbonnet L, Waddington JL, O’Tuathaigh CM. Mutant models for genes associated with schizophrenia. Biochem Soc Trans. 2009; 37(Pt 1):308-312.
110. Santacruz K, Lewis J, Spires T, et al. Tau suppression in a neurodegenerative mouse model improves memory function. Science. 2005;309(5733):476-481.

111. Koppel J, Jimenez H, Azose M, et al. Pathogenic tau species drive a psychosis-like phenotype in a mouse model of Alzheimer's disease. Behav Brain Res. 2014;275C:27-33.

\section{Publish your work in this journal}

Neuropsychiatric Disease and Treatment is an international, peerreviewed journal of clinical therapeutics and pharmacology focusing on concise rapid reporting of clinical or pre-clinical studies on a range of neuropsychiatric and neurological disorders. This journal is indexed on PubMed Central, the 'PsycINFO' database and CAS, and is the official journal of The International Neuropsychiatric Association (INA). The manuscript management system is completely online and includes a very quick and fair peer-review system, which is all easy to use. Visit http://www.dovepress.com/testimonials.php to read real quotes from published authors.

\footnotetext{
Submit your manuscript here: http://www.dovepress.com/neuropsychiatric-disease-and-treatment-journal
} 